\title{
Pengaruh Future Time Perspective Terhadap Kematangan Karir Pada Mahasiswa
}

\author{
Aully Grashinta \\ Psikologi Pendidikan, Fakultas Psikologi, Universitas Pancasila \\ email: aullygrashinta@univpancasila.ac.id \\ Adinda Putri Istiqomah \\ Fakultas Psikologi, Universitas Pancasila \\ email: putri.adinda83@gmail.com \\ Endro Puspo Wiroko \\ Psikologi Indurstri dan Organisasi, Fakultas Psikologi, Universitas Pancasila \\ email: endro.puspowiroko@univpancasila.ac.id
}

(Diterima: 18-Januari-2018; direvisi: 03-Maret-2018; dipublikasikan: 24-Juni-2018)

\begin{abstract}
One reason of the high unemployment is the lack of career planning. The individu needs career maturity and views about the future (future time perspective) so that she/he can choose the right job. This research aimed to determine the influence of future time perspective toward career maturity in college student. This study used a quantitative approach. Sample in this study are 156 of college students in Jabodetabek.The measurement tools is Carstensen and Lang Future Time Perspective scale (CL-FTP) and Career Maturity Inventory form $\mathrm{C}$ (IMC form $\mathrm{C}$ ). The result shos that future time perspective affecting positively to career maturity in college student significantly $\left(R^{2}=0.139 ; p=0.000\right)$. Simple linear regression analysis stated that future time perspective contributed $13,9 \%$ to the career maturity and $86,1 \%$ influenced by other factors.
\end{abstract}

Keywords: future time perspective; career maturity; college student

Abstrak. Salah satu penyebab tingginya angka pengangguran adalah lemahnya perencanaan karir. Individu membutuhkan kematangan karir dan pandangan terkait masa depan (future time perspective) supaya dapat memilih pekerjaan yang tepat. Tujuan dari penelitian ini adalah untuk mengetahui pengaruh future time perspective terhadap kematangan karir pada mahasiswa. Penelitian ini menggunakan pendekatan kuantitatif. Sampel dalam penelitian ini adalah mahasiswa di Jabodetabek sebanyak 156 responden. Alat ukur yang digunakan dalam penelitian ini adalah Skala Future Time Perspective (CLFTP) dan Career Maturity Inventory form C (IMC form C). Hasil dari penelitian ini adalah future time perspective berpengaruh positif secara signifikan terhadap kematangan karir $\left(\mathrm{R}^{2}=0,139 ; \mathrm{p}=0,000\right)$. Analisis regresi linier sederhana menyebutkan bahwa future time perspective berkontribusi $13,9 \%$ terhadap kematangan karir dan $86,1 \%$ dipengaruhi oleh faktor-faktor lainnya.

Kata kunci : Future time perspective; kematangan karir; mahasiswa 


\section{PENDAHULUAN}

Perguruan tinggi merupakan lembaga pendidikan tertinggi dalam jalur pendidikan formal. Mahasiswa yang telah mengenyam pendidikan di perguruan tinggi diharapkan memiliki kompetensi atau kualitas keahlian sesuai dengan latar belakang pendidikan atau jurusan mereka, karena akan dihadapkan dengan dunia kerja sesuai dengan bidang ilmu dan keahliannya. Mahasiswa harus mampu memilih dan menentukan karir apa yang akan dijalani sebagai pekerjaanya di kemudian hari. Dengan berkarir manusia akan mampu meningkatkan potensi diri serta memenuhi segala kebutuhan kehidupan. Menurut Winkel \& Hastuti (dalam Susantoputri, 2014) karir memiliki makna lebih mendalam dibandingkan pekerjaan, karena mencakup suatu proses yang terjadi di sepanjang kehidupan seseorang termasuk di dalamnya pekerjaan.

Berkarir di era globalisasi ini bukan hal yang mudah. Perkembangan kondisi ekonomi, sosial, dan budaya masyarakat yang semakin pesat mengharuskan setiap individu untuk berkompetisi dalam meningkatkan kompetensi sehingga mampu menjawab tantangan yang diminta oleh dunia industri. Rianto (2008) mengungkapkan ada beberapa tantangan yang akan dihadapi mahasiswa dalam menentukan karir yakni ketidakpastian karir, pengaksesan informasi dan program pengembangan karir, serta tantangan-tantangan ekonomi dan teknologi.

Data Badan Pusat Statistik tahun 2016 menyebutkan bahwa jumlah pengangguran menurun dari 7,45 juta orang di tahun 2015 menjadi 7,02 di tahun 2016. Namun demikian, yang mengkhawatirkan adalah adanya peningkatan pengangguran lulusan S1 dari 5,34\% di tahun 2015 menjadi sebesar 6,22\% di tahun 2016. Penduduk bekerja masih didominasi oleh mereka yang berpendidikan SD ke bawah sebesar $45,19 \%$. Sementara penduduk bekerja dengan pendidikan sarjana ke atas hanya sebesar 8,29\% (BPS, 2016).

Hasil survei menyebutkan bahwa $91 \%$ kalangan dunia usaha beranggapan bahwa lulusan perguruan tinggi tidak siap pakai selepas kuliah (Rachmawati, 2012). Menteri Tenaga Kerja, Hanif Dhakiri juga mengatakan tingginya tingkat pendidikan tidak didukung kecukupan kompetensi sehingga lulusan perguruan tinggi tidak mendapat kesempatan kerja (Harian Nasional, 2016). Faktor lain yang menjadi penyebab tingginya angka pengangguran ialah lemahnya perencanaan karir lulusan perguruan tinggi (Greenbank, dkk, 2009).

Berdasarkan dari hasil penelitian yang sudah diuraikan, kurangnya kompetensi dan lemahnya perencanaan karir mahasiswa disebabkan rendahnya kematangan karir mahasiswa. Rendahnya kematangan karir membuat mahasiswa kesulitan dalam memilih karir. Dengan demikian, setelah menyelesaikan pendidikan tingkat sarjana, mereka belum siap untuk menghadapi persaingan dunia kerja.

Kematangan karir merupakan kesiapan individu dalam pemilihan karir, serta proses pengambilan keputusan karir yang sesuai dengan tugas perkembangan karir (Rehfuss \& Sickinger 2015). Hasil wawancara yang dilakukan El Hami (2006) pada mahasiswa di salah satu Universitas di Indonesia mengaku belum mengetahui bidang pekerjaan yang akan dijalaninya sebagai karir, terkait dengan program studinya, bahkan ketika pertama kali memutuskan untuk memilih jurusan di perguruan tinggi pun tanpa didasari dengan pertimbangan yang matang mengenai prospek dan bidang-bidang pekerjaan yang akan dijalaninya sesuai dengan latar belakang yang pendidikan yang ditempuh. Hasil wawancara tersebut terlihat bahwa kematangan karir yang rendah dibuktikan dengan kurangnya persiapan yang matang dalam pemilihan jurusan ketika memasuki dunia perkuliahan, hal ini juga dapat berakibat pemilihan pekerjaan yang tidak sesuai dengan latar belakang studi.

Merujuk pada tugas perkembangan, usia mahasiswa berada pada tahap pencapaian individu dalam menggunakan pengetahuannya untuk mendapatkan kompetensi dan independensi dalam rangka mengejar target seperti karir dan keluarga (Papalia, dkk, 2008). Hurlock (2004) juga mengatakan bahwa mahasiswa masuk ke dalam fase dewasa awal (21-40 tahun) di mana tugas perkembangannya adalah mencapai prestasi, memilih pasangan, belajar hidup dengan pasangan, memelihara anak, mengurus rumah tangga dan karir. Dengan demikian, mahasiswa sudah harus berada pada proses eksplorasi karir yang diminati untuk dapat memiliki pilihan karir yang akan ditekuni di masa depan. Pandangan individu mengenai segala sesuatu pada masa depannya berkaitan pula dengan future time perspective.

Lens (2012) menyatakan bahwa future time perspective dapat memotivasi individu dalam pengembangan karir di masa depan. Future time perspective (FTP) adalah 
kecenderungan yang berbeda pada tiap individu mengenai pemikiran tentang masa depan (Betts, 2013). Future time perspective dapat berfungsi sebagai kekuatan motivasi bagi individu untuk terlibat dalam aktivitas yang bisa membantu untuk mencapai hasil di masa depan (McInerney, 2004). Individu yang memiliki future time perspective tinggi akan beranggapan bahwa mereka memiliki kesempatan yang besar di masa depan dan berusaha untuk mencapai tujuannya dengan mengembangkan dan meningkatkan keterampilan saat ini (Simon, 2004).

Betts mengidentifikasi dua dimensi dari future time perspective yaitu (1) fokus pada kesempatan (focus on opportunities) dan (2) fokus pada keterbatasan (focus on limitations). Individu yang merasa memiliki banyak kesempatan di masa depan (high focus on opportunities) akan lebih termotivasi, investasi lebih banyak pada sumber pribadi, dan merasa akhir yang masih jauh. Sedangkan, individu yang merasa memiliki masa depan yang terbatas (high focus on limitations) akan kurang termotivasi, investasi lebih sedikit pada sumber pribadi, dan merasa akhir yang dekat (Betts, 2013).

Future time perspective diketahui berkorelasi dengan kematangan karir. Hal tersebut dibuktikan dengan penelitian yang dilakukan oleh Cheng et al (2016) terhadap 431 mahasiswa keperawatan yang menunjukkan hasil bahwa future time perspective berkorelasi positif dengan kematangan karir. Ketika individu memiliki future time perspective yang tinggi maka individu tersebut memiliki kematangan karir yang tinggi. Dampak yang ditimbulkan ketika mahasiswa memiliki future time perspective yang tinggi adalah mereka tidak akan merasa cemas dalam persaingan dunia kerja karena sudah memiliki kesiapan yang matang dari segi mental dan kognitif, serta telah mantap dengan pemilihan karir atau pekerjaan yang sesuai dengan mereka. Hal tersebut didukung oleh penelitian yang menunjukkan bahwa pelajar yang memiliki imajinasi masa depan mampu membuat sebuah skema yang berfungsi sebagai strategi pembelajaran saat ini untuk pencapaian masa depan, dan akan terus berkembang sehingga dimasa depan akan siap untuk memasuki dunia kerja. (Oyserman, 2004 ; Hilpert. J, dkk, 2012)

Tujuan dari penelitian ini adalah untuk mengetahui pengaruh future time perspective terhadap kematangan karir dengan menggunakan sampel mahasiswa Jabodetabek karena adanya peningkatan angka pengangguran yang signifikan dari lulusan perguruan tinggi yang terdiri dari berbagai macam bidang studi.

Berdasarkan latar belakang yang telah diuraikan, maka rumusan masalah penelitian ini adalah apakah terdapat pengaruh yang signifikan antara future time perspective terhadap kematangan karir pada mahasiswa.

Kematangan karir merupakan sebuah kemampuan individu dalam menentukan sendiri mengenai pekerjaan yang sesuai dengan minat dan kemampuan, pilihan yang realistik dan konsisten (Sharf, 2006). Sementara Savickas (dalam Rehfuss \& Sickinger, 2015) mengatakan bahwa kematangan karir merupakan kesiapan individu dalam pemilihan karir, serta proses pengambilan keputusan karir yang sesuai dengan tugas perkembangan karir. Creed dan Prideaux (2001) mendefinisikan kematangan karir sebagai kesiapan individu untuk mengatasi tugas-tugas perkembangan pada tahap pertumbuhan, eksplorasi, peningkatan, pemeliharaan dan pelepasan. Definisi yang digunakan dalam penelitian ini adalah definisi menurut Savickas yaitu kematangan karir merupakan kesiapan individu dalam pemilihan karir, serta proses pengambilan keputusan karir yang sesuai dengan tugas perkembangan (Rehfuss \& Sickinger, 2015).

Faktor yang mempengaruhi kematangan karir remaja terdiri dari faktor internal dan faktor eksternal. Faktor internal antara lain adalah nilainilai kehidupan yang menjadi pedoman hidup, taraf kecerdasan, bakat khusus, minat, sifat atau ciri kepribadia, pengetahuan dan informasi yang dimiliki, dan keadaan jasmani. Sementara faktor eksternal yakni masyarakat dan lingkungan sosial budayanya, keadaan sosial ekonomi negara atau daerah, status sosial ekonomi keluarga, pengaruh dari anggota keluarga besar dan inti, tempat pendidikan atau sekolah, pergaulan dengan teman sebaya, dan tuntutan yang melekat pada masing-masing jabatan pada jenis pekerjaan (Winkel \& Hastuti, 2006).

Rehfuss \& Sickinger, (2015) menjelaskna empat dimensi dari kematangan karir, yaitu concern, curiosity, confidence, dan consultation. Concern adalah kemampuan individu untuk berorientasi dalam merencanakan masa depan yang terlibat dalam proses pembuatan keputusan karir. Curiosity merujuk pada sejauh mana individu menjelajahi dunia kerja dan mencari informasi tentang pekerjaan dan kebutuhan dalam perencanaan karirnya. Confidence dijelaskan sebagai sejauh mana individu memiliki keyakinan dalam dirinya atau 
kemampuannya dalam membuat keputusan karir secara bijaksana dan membuat pilihan pekerjaan sesuai dengan pengetahuan prestasi yang dimiliki. Sementara consultation adalah saat Individu mencari bantuan dalam pengambilan keputusan karir dengan meminta informasi atau saran dari orang lain dan mengambil tindakan untuk memutuskan karirnya

Future time perspective (FTP) adalah kecenderungan yang berbeda pada tiap individu untuk berpikir tentang masa depan (Betts, 2013). Future time perspective didefinisikan sebagai persepsi individu tentang masa depannya (Husman dan Shell 2008). Sedangkan Froehlich, (2015) mendefinisikan future time perspective sebagai persepsi seseorang mengenai seberapa banyak kesempatan dan keterbatasan dalam kehidupan mereka. Terdapat dua dimensi dari future time perspective yaitu fokus pada kesempatan (focus on opportunities) dan fokus pada keterbatasan (focus on limitations) (Betts, 2013). Fokus pada kesempatan diartikan sebagai tingkat perhatian individu pada kemungkinan atau kesempatan dalam hidupnya, sedangkan fokus pada keterbatasan didefinisikan sebagai tingkat perhatian individu pada keterbatasan dalam hidupnya. Individu yang memiliki skor future time perspective tinggi dapat diartikan bahwa individu tersebut memiliki tingkat fokus pada kesempatan yang tinggi atau menilai bahwa ia masih memiliki banyak peluang/kesempatan dalam hidupnya. Sedangkan, individu yang memiliki skor future time perspective rendah dapat diartikan bahwa individu tersebut memiliki tingkat fokus pada keterbatasan yang tinggi atau menilai bahwa peluang/kesempatan yang ia miliki terbatas.

\section{METODE PENELITIAN}

Pendekatan penelitian yang digunakan adalah pendekatan kuantitatif-non eksperimental. Subjek dalam penelitian ini berjumlah 156 mahasiswa aktif yang tersebar di wilayah Jabodetabek.

Untuk mengukur kematangan karir digunakan alat ukur Career Maturity Inventory form $C$ (CMI form $C$ ) yang diadaptasi dari Crites \& Savickas (2011). Alat ukur ini terdiri dari terdiri dari 24 item yang merujuk pada dimensi kematangan karir, yaitu concern, curiosity, confidence, dan consultation yang dijelaskan oleh Rehfuss dan Sickinger (2015).

Sedangkan untuk mengukur future time perspective digunakan Skala Carstensen and Lang Future Time Perspective (CL-FTP) yang disusun oleh Carstensen and Lang (1996). Skala ini disusun berdasarkan dua dimensi, yaitu fokus pada kesempatan (focus on opportunities) dan fokus pada keterbatasan (focus on limitations). CL-FTP terdiri dari 10 item, dengan kombinasi 7 item untuk fokus pada kesempatan dan 3 item untuk fokus pada keterbatasan.

Uji reliabilitas pada skala kematangan karir menunjukkan koefisien sebesar 0,856 (Alpha Cronbach). Uji reliabilitas pada skala future time perspective menunjukkan koefisien sebesar 0,811 (Alpha Cronbach).

Metode analisis data yang digunakan pada penelitian ini adalah teknik statistik regresi linear sederhana. Analisis regresi linear sederhana digunakan untuk melihat bagaimana pengaruh antara satu independent variable (IV) dan satu dependent variable (DV). Independent variable (IV) dalam penelitian ini yaitu future time perspective dan kematangan karir sebagai dependent variable (DV).

\section{HASIL}

Uji hipotesis dilakukan dengan analisis regresi linear sederhana. Nilai $\mathrm{R}$ square yang diperolah sebesar 0,139. Hal ini berarti bahwa future time perspective berpengaruh terhadap kematangan karir pada mahasiswa adalah sebesar $13,9 \%$ sedangkan sisanya sebesar $86,1 \%$ dipengaruhi oleh faktor lain.

Tabel 1. Hasil Uji Regresi Linear Sederhana

\begin{tabular}{ccccc}
\hline $\begin{array}{l}\text { Mo } \\
\text { del }\end{array}$ & $R$ & $R$ Square & $\begin{array}{c}\text { Adjusted } R \\
\text { Square }\end{array}$ & $\begin{array}{c}\text { Std. } \\
\text { Error of } \\
\text { the } \\
\text { Estimate }\end{array}$ \\
\hline 1 &, $373^{\mathrm{a}}$ &, 139 &, 134 & 5,58426 \\
\hline \multicolumn{4}{l}{ a. Predictors: (Constant), FTP }
\end{tabular}

Selanjutnya dilakukan pengujian ANOVA untuk dapat melihat apakah model regresi (future time perspective berpengaruh terhadap kematangan karir pada mahasiswa) layak digunakan.

Tabel 2. Hasil Anova Pengaruh Future Time Perspective Terhadap Kematangan Karir Pada Mahasiswa

ANOVA $^{\mathrm{a}}$ 


\begin{tabular}{|c|c|c|c|c|}
\hline Model & $\begin{array}{c}\text { Sum of } \\
\text { Squares }\end{array}$ & $d f$ & $\begin{array}{c}\text { Mean } \\
\text { Square }\end{array}$ & $F$ \\
\hline $\begin{array}{l}\text { Regress } \\
\text { ion }\end{array}$ & 776,824 & 1 & 776,824 & $\begin{array}{c}24,91 \\
1\end{array}$ \\
\hline${ }_{1} \underset{l}{\text { Residua }}$ & 4802,323 & $\begin{array}{c}15 \\
4\end{array}$ & 31,184 & \\
\hline Total & 5579,147 & $\begin{array}{c}15 \\
5\end{array}$ & & \\
\hline
\end{tabular}

a. Dependent Variable: $K K$

b. Predictors: (Constant), FTP

Berdasarkan tabel 2 di atas dapat disimpulkan bahwa model regresi tersebut layak, artinya future time perspective dapat digunakan untuk memprediksi kematangan karir pada mahasiswa, $\mathrm{F}(24,911), p=0,000(p<0,05)$. Dapat disimpulkan bahwa terdapat pengaruh yang signifikan future time perspective terhadap kematangan karir pada mahasiswa.

Temuan dalam penelitian ini adalah terdapat pengaruh positif future time perspective terhadap kematangan karir pada mahasiswa. Hal tersebut sesuai atau mendukung dari hasil penelitian sebelumnya mengenai hubungan antara future time perspective dengan kematangan karir. Penelitian sebelumnya dilakukan oleh Cheng dkk (2016) yang menghasilkan hubungan positif antara future time perspective dengan kematangan karir, future time perspective merupakan konstruk penting yang secara tidak langsung dapat mempengaruhi komitmen individu dalam pemilihan karir.

Hasil penelitian ini juga sejalan dengan Walker dan Tracey (2012) yang menyatakan future time perspective merupakan salah satu kunci penting dalam pengambilan keputusan karir. Future time perspective mampu memotivasi mahasiswa dalam pengembangan karirnya di masa depan (Lens, 2012).

Hasil uji hipotesis dalam penelitian ini menunjukkan bahwa besarnya pengaruh antara future time perspective terhadap kematangan karir yaitu sebesar 13,9\% sementara 86,1\% kematangan karir dipengaruhi oleh faktor-faktor lain. Faktor internal yang akan mempengaruhi perkembangan karir individu adalah nilai-nilai kehidupan yang ia ikuti, bakat khusus yang dimiliki, minat, sifat dan ciri kepriibadian, informasi tentang bidang-bidang pekerjaan, serta keadaan fisik individu (Winkel dan Hastuti, 2006). Sedangkan faktor ekternal yang mempengaruhi kematangan karir mahasiswa salah satunya adalah parent attachment. Hasil penelitian Lee \& Hughey (2001) menyatakan parent attachment memainkan peran yang sangat

Sigpenting dalam kematangan karir anak, maka orang tua memiliki pengaruh dalam ,00®erkembangan aspirasi masa depan dan juga ${ }^{\text {b }}$ pemilihan karir. Faktor eksternal lainnya adalah penting adanya bimbingan karir untuk membimbing dan mengarahkan mahasiswa dalam pemilihan karirnya. Pernyataan ini didukung oleh hasil penelitian dari Juwitaningrum (2016) yang menyatakan bahwa program bimbingan karir terbukti efektif untuk meningkatkan kematangan karir.

Tingkat future time perspective dan kematangan karir responden pada penelitian ini berada pada kategori sedang sehingga belum dapat dikatakan cukup mantap dan tidak mengalami perubahan. Mahasiswa dengan future time perspective dan kematangan karir pada kategori sedang sudah memiliki gambaran akan masa depan dan perencanaan karir namun belum terlalu yakin pada kesempatan yang ia miliki. Hal itu berpengaruh pada saat ia mulai mencari pekerjaan dan dihadapkan oleh banyaknya variasi pilihan karir di berbagai lowongan pekerjaan. Mereka menemui kesulitan dalam memilih dan memutuskan tujuan karirnya. Seperti yang dikatakan oleh Hurlock (2004), masih banyak orang dewasa muda (mahasiswa) bingung tentang apa yang akan mereka kerjakan dalam hidupnya setelah selesai dari pendidikan SMA, akademi bahkan yang tamat dari perguruan tinggi sehingga, future time perspective dan kematangan karir sangat penting untuk dimiliki mahasiswa.

Future time perspective dan kematangan karir yang tinggi dapat dikembangkan dengan memperkaya wawasan akan tujuan karir di masa depan seperti mencari tahu berbagai jenis pilihan karir yang berkembang saat ini, bagaimana cara mencapainya, serta potensi kebutuhan pekerjaan di masa mendatang. Hal lain yang dapat meningkatkan tingginya future time perspective dan kematangan karir dengan cara mengikuti program bimbingan karir yang dirancang dengan tepat dan relevan sehingga dapat mendorong mahasiswa untuk meningkatkan kompetensi yang dibutuhkan oleh dunia kerja. Salah satu masalah yang dihadapi adalah kompetensi yang dimiliki kurang sesuai dengan apa yang dibutuhkan oleh perusahaan. Dengan demikian, para pencari kerja sulit mencari pekerjaan yang sesuai dan berdampak pada bertambahnya jumlah pengangguran di Indonesia. 


\section{SIMPULAN DAN SARAN}

Secara keseluruhan dapat disimpulkan bahwa future time perspective dapat mempengaruhi kematangan karir pada mahasiswa sehingga, penting bagi mahasiswa untuk meningkatkan pemahaman mengenai future time perspective dan memperluas wawasan mengenai karir.

Keterbatasan dari penelitian ini adalah kurang lengkapnya data mengenai minat penjurusan kuliah sudah sesuai dengan yang diinginkan atau belum, alasan pengambilan jurusan di perguruan tinggi, dan sebagainya agar dapat memperkaya hasil penelitian. Penelitian selanjutnya dapat menghubungkan kematangan karir dengan variabel eksternal seperti atau pengaruh teman sebaya atau peer untuk menjelaskan faktor eksternal yang mempengaruhi kematangan karir, sehingga penelitian lain mengenai kematangan karir mahasiswa dapat berkembang.

\section{DAFTAR PUSTAKA}

Betts, M. (2013). Future time perspective: Examination of multiple conceptualizations and work-related correlates (Tesis).

BPS. (2016). Februari 2016: Tingkat Pengangguran Terbuka (TPT) Sebesar 5,50 Persen. Diunduh dari www.bps.go.id pada tanggal 4 Mei 2017 pukul 19.22.

Creed, P, A., Lee-Ann, P. (2001). Career maturity, career decision-making selfefficacy and career indecision: a review of the accured evidence. Journal of Career Development, ACER (Australian Council for Educational Research). 10 (2), 1-22.

Cheng, C., Liu, Y., Yuxia, C., Huijing, Z.,Yonggang, S., Xiuzhen, F.(2016). Attributions, future time perspective and career maturity in nursing undergraduates: correlational study design. BMC medical education.

El Hami, A., Zahroturrosyida, H., Mariana, S. (2006). Gambaran kematangan karir pada para calon sarjana di lingkungan fakultas psikologi Universitas Padjajaran. Laporan Penelitian.

Froehlich, D. E., Simon, A. J. B. \& Mien, S. R. S. (2015). Great expectations: the relationship between future time perspective, learning from others, and employability. Vocations and learning, 8, 213-227.

Greenbank, P., Hepworth, S. \& Mercer, J. (2009). Term-time employment and the student experience. Education and Training, 51(1), 43-55.

Husman, J. and Shell, D. F. (2008). Beliefs and perceptions about the future: A measurement of future time perspective. Learning and Individual Differences 18(2), 166-175

Hurlock, E. B. (2004). Psikologi perkembangan. Jakarta: Penerbit Erlangga.

Hilpert, J. J. Husman, G. S. Stump,W.kim, W.T. Chung, M. A. Duggan. (2012). Examining students' future time perspective: pathways to knowledge building. Japanese Psychological Research, 54(3), 229-240.

Juwitaningrum. (2016). Program bimbingan karir untuk meningkatkan kematangan karir siswa SMK. Jurnal Univeritas Ahmad Dahlan, 2(2).

Lens W, PaixAO MP, Herrera D, Grobler A. (2012). Future time perspective as a motivational variable: content and extension of future goals affect the quantity and quality of motivation. Japane Psychological Research, 54(3), 321.

Lee, Hee-Yeong \& Hughey, Kenneth.F. (2001). The relationship of psychological separation and parental attachment to the career maturity of college freshmen from intact families. Journal of career development. 27(4), 279293.

McInerney, D. M. (2004). A discussion of future time perspective. Educational Psychology Review, 16(2), 141-151.

Papalia, D.E., Olds, S.W., \& Feldman, R.D. (2008). Human development (psikologi perkembangan). Jakarta: Prenada Media Group.

Rachmawati, Y. (2012). Hubungan antara self efficacy dengan kematangan karir pada mahasiswa tingkat awal dan tingkat akhir di Universitas Surabaya. Jurnal Ilmiah Universitas Surabaya. 1(1), 1-25.

Rehfuss, M.C., \& Sickinger, P.H. (2015). Assisting high school students with career indecision using a shortened from of the career construction interview. Journal of school counseling. 13(6), p1-23. 23p. 
Rianto, A. (2008). Tantangan karir mahasiswa. Diunduh dari www.re-searchengines.com pada tanggal 2 Mei 2017 pukul 21.07

Sharf, R. S. (2006). Applying career development theory (4th ed). United States: Thomson Brooks/Cole.

Simon J, Vansteenkiste M, Lens W, Lacante M. (2004). Placing motivation and future time perspective in a teporal perspective. Educ Psychol Rev.16(2), 121.
Susantoputri., Maria, K., William, G. (2014). Hubungan antara karier dengan kematangan karier pada masa remaja di daerah Kota Tangerang. Jurnal Psikologi, 10(1), 67-73.

Walker TL, Tracey TJG. (2012). The role of future time perspective in career decisionmaking. Journal of vocational behaviour, 81(3), 150.

Winkel, W.S., \& Hastuti,S. (2006). Bimbingan dan konseling di institusi pendidikan. Jakarta: Media Abadi. 